\title{
A study of brown-marbled grouper (Epinephelus fuscoguttatus) population dynamics in Takabonerate National Park Waters, South Sulawesi, Indonesia
}

\author{
FATMA $^{1, \boldsymbol{v}}$, ACHMAR MALLAWA ${ }^{2}$, NAJAMUDDIN ${ }^{2}$, MUKTI ZAINUDDIN ${ }^{2}$, FACHRIE REZKA AYYUB $^{3}$ \\ ${ }^{1}$ Doctoral Program of Fisheries Science, Faculty of Marine Science and Fisheries, Universitas Hasanuddin. Jl. Perintis Kemerdekaan, Tamalanrea, \\ Makassar 90245, South Sulawesi, Indonesia. Tel.: +62-411-585034, Fax.: +62-411-585868, •email: fatma.rezka @gmail.com \\ ${ }^{2}$ Department of Marine Science and Fisheries, Faculty of Marine Science and Fisheries, Universitas Hasanuddin. Jl. Perintis Kemerdekaan, Tamalanrea, \\ Makassar 90245, South Sulawesi, Indonesia \\ ${ }^{3}$ Environmental Education Graduate Program, Universitas Negeri Makassar. Jl. Bontolangkasa, Gunung Sari, Makassar 90222, South Sulawesi, \\ Indonesia
}

Manuscript received: 6 August 2021. Revision accepted: 22 September 2021.

\begin{abstract}
Fatma, Mallawa A, Najamuddin, Zainuddin M, Fachrie R. 2021. A study of brown-marbled grouper (Epinephelus fuscoguttatus) population dynamics in Takabonerate National Park Waters, South Sulawesi, Indonesia. Biodiversitas 22: $4298-4307$. Understanding aspects of the population dynamics of groupers such as the brown-marbled grouper can provide valuable insights into how to manage grouper stocks effectively. Conducted from February 2020 to February 2021 in Takabonerate National Park waters, Selayar Islands District, South Sulawesi, Indonesia, this study sought to elucidate the size structure and cohorts, population growth rate, total mortality rate, fishing mortality rate, natural mortality rate, exploitation rate and yield per recruit (Y/R) of the brown-marbled grouper. Grouper samples were caught using several fishing gears (i.e., hand line fishing, spearfishing, and trapping) with a total catch of 1042 specimens. The sampled specimens exhibited significant size structure and were classified into five age-specific cohorts. The growth rate coefficient was 0.46 year, with the brown-marbled grouper population tending to exhibit slow growth (K $<0.5 /$ year). The estimated asymptotic length was $109.0 \mathrm{~cm}$. The fishing mortality was higher than the natural mortality, with an exploitation rate of 0.65 , indicating that brown-marbled groupers in the waters of Takabonerate National Park have been subjected to extensive and intensive fishing, as also indicated by an estimated Y/R lower than the optimum Y/R rate.
\end{abstract}

Keywords: Cohorts, exploitation rate, growth, mortality, Takabonerate, yield per recruit

\section{INTRODUCTION}

Indonesian Fishing Management Area (FMA) 713 comprises the Makassar Strait, Bone Bay, and Flores Sea. According to the Indonesian Ministry for Marine Affairs and Fisheries (MMAF), the estimated maximum sustainable yield (MSY) for reef fish in FMA 713 is 292,336 tons per year with an estimated annual exploitation rate of 0.34 (MMAF 2016).

Within FMA 713, the waters of Takabonerate National Park (TNP), Selayar Islands District, South Sulawesi, Indonesia, in the Flores Sea are rich in reef fish species, including the brown-marbled grouper. In general, local fishing activities entail commercial purposes, with fish marketed in domestic and global trades. Fishers operating in the TNP still use traditional fishing gears, and fishing is generally carried out in the traditional fishing zones with an area of 481,334 ha. These zones within the TNP are specifically designated as fishing grounds where traditional fishing communities have fished for generations. The utilization of reef fish is subject to the regulatory framework in vigor, including general and specific fisheries laws and policies. Legal instruments include Act Number 5 of 1990 concerning the Conservation of Biological Natural Resources and Ecosystems, Act Number 31 of 2004 on
Fisheries, Act Number 45 of 2009 amending Act Number 31 of 2004, Government Regulation of the Minister of Environment and Forestry of the Republic of Indonesia Number P.92/MENLHK/SETJEN/KUM.1/8/2018 regarding Amendment to Regulation of the Minister of Environment and Forestry Number P.20/MENLHK/SETJEN/KUM.1/6/2018 Regarding Protected Plant and Animal Species; Regulation of the Minister of Marine Affairs and Fisheries PER.2/MEN/2011 concerning Fishing Lanes, Placement of Fishing Equipment and Fishing Aids in the Fisheries Management Areas of the Republic of Indonesia (Balai Taman Nasional Takabonerate 2019).

The implementation of rational utilization and sustainable management calls for data as a basis for understanding fish population dynamics. These data should include key parameters related to population growth rates, population recruitment processes, and the decreases in biomass or abundance in a given population due to natural mortality and fishing mortality (Mallawa 2011). Furthermore, data and information that highlight size structure, the number of age groups or cohorts present, the population growth rate, recruitment and exploitation rate of a given population are central to the fundamental understanding and implementation of fish stock assessments (Mallawa et al. 2014, 2015). 
There is an increasing trend in fishing efforts for the brown-marbled grouper in the waters of Takabonerate National Park due to the demand for and economic importance of this fish. In the last decade, Selayar Islands District grouper (Epinephelus sp., Plectropomus leopardus, Cromileptes altivelis, Cephalopolis sp.) production totaled 8190.2 tons (South Sulawesi Fisheries Statistics Data 20102019). Consequently, there is increasing concern that current and projected fishing pressure will lead to overexploitation of the population of brown-marbled grouper leading to growth disruption and poor recruitment rates. The application of sustainable management practices is therefore considered necessary.

As excessive levels of fishing pose serious risks to the fish population (stock) and ecosystem, fisheries management is vital but needs to be based on sound data. To fulfill that need, this study elucidates key aspects of brown-marbled grouper population dynamics in the waters of Takabonerate National Park, including size structure and cohorts, population growth rate, exploitation rate, and yield per recruit. These data will inform fisheries management and support the achievement of sustainable fisheries management objectives.

\section{MATERIALS AND METHODS}

\section{Time and place of the study}

The study was conducted over one full year, from February 2020 to February 2021, in the waters of Takabonerate National Park (TNP) in Selayar Islands District, South Sulawesi, Indonesia. Sampling was carried out at the fishing bases from which the TNP fishermen usually fish around several islands within the Park, including Rajuni Island, Jinato Island, and Tarupa Island (Figure 1).

\section{Data collection}

Quantitative data collected were the total length (TL, $\mathrm{cm})$ and weight $(\mathrm{kg})$ of harvested fish, measured at the fishharvesting site. Qualitative data included direct observation of daily fishing operations and the fishing methods used to capture brown-marbled grouper in the waters of Takabonerate National Park. The primary fishing gears/methods were hand lines, traps, and spear guns. Using the method illustrated in Figure 2, 1042 brownmarbled grouper specimens were measured over the study period (February 2020-February 2021). Gender is determined by looking at the morphology of the gonads in each fish sample dissected. After knowing the gender of each fish, the ratio of male and female fish can be known.

\section{Data analysis}

\section{Size structure}

The fish size structure was analyzed descriptively based on $10 \mathrm{~cm}$ length classes and $2 \mathrm{~kg}$ weight classes. Size class frequencies were displayed as histograms based on class midpoints for the sample as a whole and disaggregated by sex.

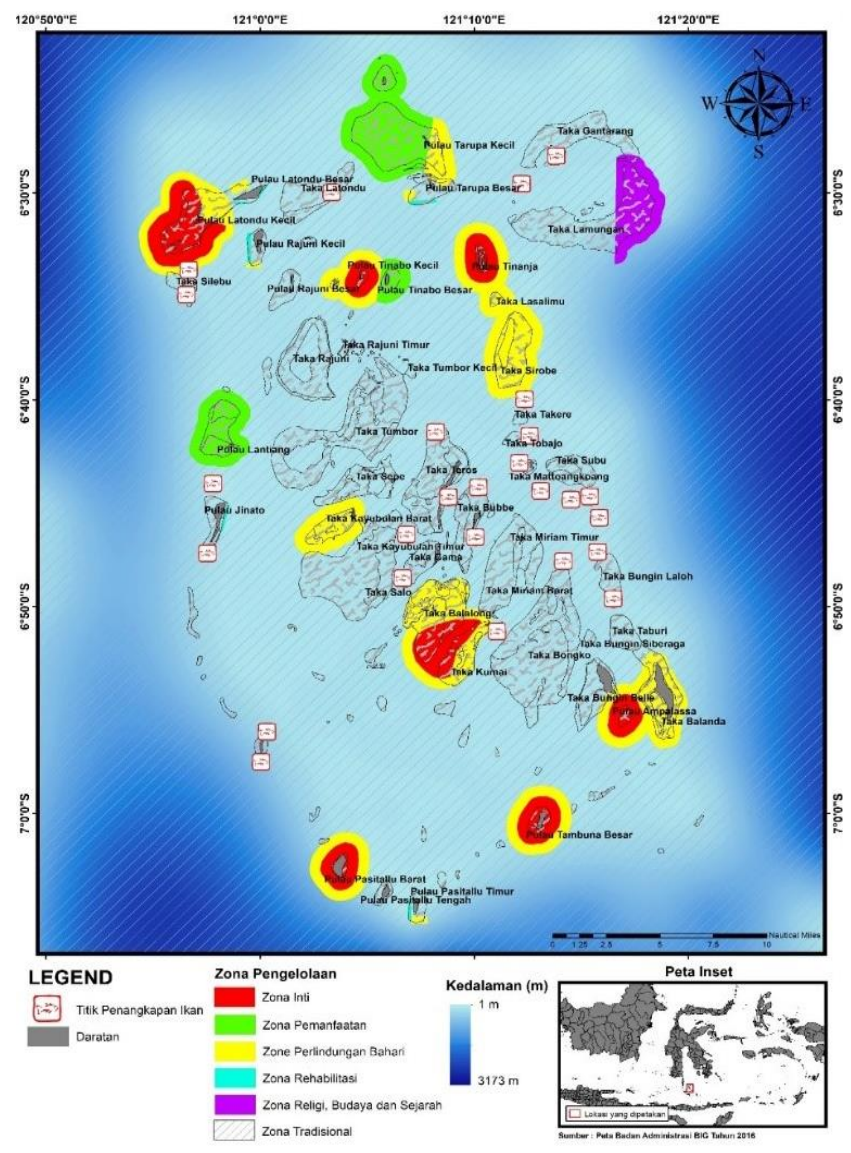

Figure 1. Map of the study site in Takabonerate National Park, Selayar Islands District, South Sulawesi, Indonesia. Red and white boxes indicate fishing grounds. Zone legend: Red: core zone; green: monitoring zone; yellow: marine protected zone; turquoise: rehabilitation zone; purple: cultural and historical protection zone; grey: land; uncolored (with blue depth scale): traditional fishing zone

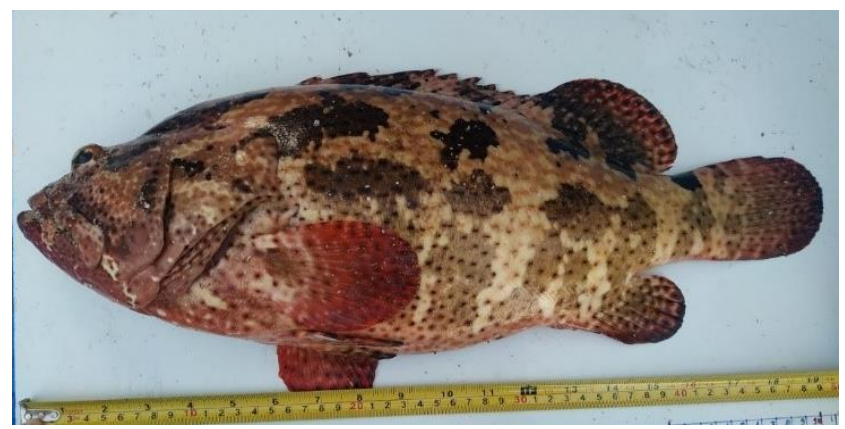

Figure 2. A brown-marbled grouper specimen measured during the study in the waters of Takabonerate National Park, Selayar Islands District, South Sulawesi, Indonesia

\section{Cohorts}

Data processing was performed using the FAOICLARM stock assessment tools II (FiSAT II) software package (Gayanilo et al. 2005). The number of age-based cohorts was determined through analysis of the lengthfrequency data for brown-marbled groupers in the waters of Takabonerate National Park using the logarithmic 
difference of frequency method (Bhattacharya 1967). This method applies the following equations:

$$
\begin{aligned}
& y^{\prime}=\Delta \ln F c(x+d L / 2)-\Delta \ln F c(z) \\
& y=(d L x /)-d L(x+d L / 2) / \text { or } y=a+b x \\
& a=d L x /, b=d L /, z=x+d L / 2
\end{aligned}
$$

$\mathrm{X}$ may also be fitted using the following formula:

$$
X=-\mathbf{a} / \mathbf{b}
$$

Where: $a$ : intercept; $b$ : slope

To obtain a normal frequency distribution, the observed frequency (Fobs) was converted into calculated frequency $(\mathrm{Fc})$ based on the normal distribution equation (Sparre et al. 1999):

$$
\mathbf{F c}=\frac{n \cdot d L}{S \sqrt{2 n}}\left[\frac{-(X-X)^{2}}{2 S^{2}}\right]
$$

Where: Fc: calculated frequency; n: number of fish; dl: interval class; S: standard deviation; $\mathrm{x}$ : average length; $\mathrm{X}$ : average class total length; $\pi$ : 3.1415 .

\section{Growth}

Data processing was performed using the ELEFAN I package in the FAO-ICLARM stock assessment tools II (FiSAT II) software package (Gayanilo et al. 2005). The growth of brown-marbled grouper was described using the van Bertalanffy exponential growth equation (Sparre et al. 1989):

$$
\mathbf{L t}=\mathbf{L} \infty\left[1-e^{-K(t-t o)}\right]
$$

Where: $\mathrm{L}_{\mathrm{t}}$ : fish length at age $\mathrm{t}$ (years); $\mathrm{L}_{\infty}$ : asymptotic length $(\mathrm{cm})$; K: growth coefficient $\left(\right.$ year $\left.^{-1}\right)$.

To obtain the asymptotic length $\left(L_{\infty}\right)$ and the growth coefficient $(\mathrm{K})$, Ford and Walford's method was adopted, through which $\mathrm{L}(\mathrm{t}+\Delta \mathrm{t})$ and $\mathrm{L}(\mathrm{t})$ were plotted using the following equation:

$$
\mathbf{L}(\mathbf{t}+\Delta \mathbf{t})=\mathbf{a}+\mathbf{b} . \mathbf{L}(\mathbf{t})
$$

This equation constitutes a regression of a dependent variable and an independent variable which is equivalent to the linear equation:

$\mathbf{Y}=\mathbf{a}+\mathbf{b} \mathbf{x}$

Where: a: $\mathrm{L}_{\infty}(1-\mathrm{b})$; b: $\exp (-\mathrm{K} . \Delta \mathrm{t})$

The resulting formula can be transformed as:

$$
\begin{aligned}
& \mathbf{L} \infty=\frac{a}{1-b} \\
& \mathbf{K}=\frac{-1}{\Delta t} \ln b
\end{aligned}
$$

The growth parameter t0 was obtained from the formula proposed by Pauly (1984):

$$
\log (-t 0)=-0.3922-0.2752\left(\log L_{\infty}\right)-1.038(\operatorname{LogK})
$$

Where: Lo: fish asymptotic length $(\mathrm{cm}) ; \mathrm{K}$ : coefficient of growth rate (per year); $\mathrm{t}_{0}$ : theoretical age by the time fish length was equal to zero (year).

\section{Mortality}

Total mortality. Data processing was performed using the FAO-ICLARM stock assessment tools II (FiSAT II) software package (Gayanilo et al. 2005). Total mortality rate $(Z)$ was estimated using the linearized lengthconverted catch curve analysis (Pauly 1984; Mallawa and Amir 2019) represented in the equation below:

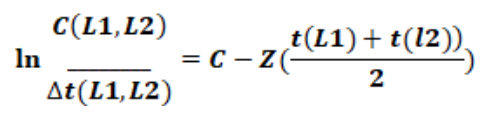

Where: $\mathrm{y}: \ln \mathrm{C}(\mathrm{L} 1, \mathrm{~L} 2) / \Delta \mathrm{t}(\mathrm{L} 1, \mathrm{~L} 2) ; \mathrm{x}:\{\mathrm{t}(\mathrm{L} 1)+\mathrm{t}$ (L2) $\} / 2$ and slope (b) $=-\mathrm{Z}$.

Natural mortality. Data processing was performed using the FAO-ICLARM stock assessment tools II (FiSAT II) software package (Gayanilo et al. 2005). A reasonable estimation of natural mortality (M) was obtained using the empirical method of Pauly (1984), applying the following equation:

$\mathrm{M}=0.8 * \exp [-0.0152-0.279 * \ln \mathrm{L} \infty+0.6543 \ln \mathrm{K}+0.463 \mathrm{~T}]$

Where: M: natural mortality; Lo: asymptotic length; K: growth rate; $\mathrm{T}$ : water temperature at which fish was captured. The temperature used was $30^{\circ} \mathrm{C}$, based on field observations.

Fishing mortality. The rate of fishing mortality (F) was estimated using the following equation:

$$
\mathrm{F}=\mathrm{Z}-\mathrm{M}
$$

\section{Exploitation rate}

Exploitation rate was estimated using the equation by Beverton and Holt (Sparre et al. 1999) as presented below:

$$
E=F / Z
$$

Where: F: fishing mortality (per year); Z: total mortality rate (per year); $\mathrm{M}$ : natural mortality (per year); E: exploitation rate (per year).

\section{Yield per Recruit(Y/R)}

Data processing was performed using the FAOICLARM stock assessment tools II (FiSAT II) software package (Gayanilo et al. 2005).The rate of Yield per recruit (Y/R') was observed using the equation of Beverton and Holt (Sparre and Venema 1999): 


$$
\begin{aligned}
& (\mathrm{Y} / \mathrm{R})={ }^{E \cdot U^{M / K}}\left[1-\frac{3 U}{1+m}+\frac{3 U^{2}}{1+2 m}-\frac{U^{3}}{1+3 m}\right] \\
& U=1-\frac{L C}{L \infty}, m=\frac{1-E}{M / K}
\end{aligned}
$$

Where: E: exploitation rate (per year); Lc: the smallest length of catch sample $\geq 50 \%(\mathrm{~cm}) ; \mathrm{M}$ : natural mortality rate (per year); K: coefficient of growth rate (per year); L $\infty$ : asymptotic length $(\mathrm{cm})$.

\section{RESULTS AND DISCUSSION}

\section{Size structure}

A total of 1042 brown-marbled grouper were caught at the study sites in the waters of Takabonerate National Park within the one-year study timeframe (February 2020February 2021). The size range for both sexes combined was $23 \mathrm{~cm}$ to $97 \mathrm{~cm}$, with a dominant size class of $50-60$ $\mathrm{cm}$ TL and mean TL $=57.28 \pm 12.76 \mathrm{~cm}$ (Figure 3 ). The male grouper size range was $47 \mathrm{~cm}$ to $97 \mathrm{~cm}$, with a dominant size range of $60-70 \mathrm{~cm}$ TL and mean length of $\mathrm{TL}=65.96 \pm 9.66 \mathrm{~cm}$ (Figure 4). The female grouper size range was $23 \mathrm{~cm}$ to $73 \mathrm{~cm}$, with a dominant size range of $40-50 \mathrm{~cm}$ TL and mean length of TL $=46.84 \pm 6.83 \mathrm{~cm}$ (Figure 5).

\section{Length structure}

Differences in fish length may generally be attributable to internal factors, such as growth pattern and size at the first maturity, as well as external factors, such as differences in habitat conditions and the types of food available (Mallawa and Amir 2019). The sex-related differences observed in this study are typical of predominantly protogynous fishes such as most (but not all) groupers (Khasanah et al. 2019), including $E$. fuscoguttatus (Pears et al. 2006). Based on data from Australia, the reproductive pattern of E. fuscoguttatus is described as monandric protogynous hermaphroditism (Pears et al. 2006). This means that fish initially mature and function sexually as females, with some individuals undergoing a sex change to become males over a wide range of sizes and ages. As in the Australian study, the presence of a few females in larger size classes does indicate that some individuals do not change sex, becoming exceptionally large females. Known as f big old fat fecund female fish (BOFFFs), they can make a disproportionally large contribution to the reproductive potential of the population (Hixon et al. 2014).

\section{Weight structure $(\mathrm{Kg})$}

For both sexes combined, the weight of brown-marbled grouper ranged between $0.5 \mathrm{~kg}$ and $17.6 \mathrm{~kg}$, with a dominant weight class of $2.5-4.5 \mathrm{~kg}$ and a mean weight of $4.29 \pm 2.71 \mathrm{~kg}$ (Figure 6). The weight of males ranged from $1.65 \mathrm{~kg}$ to $17.6 \mathrm{~kg}$, with a dominant weight class of 4.5 $6.5 \mathrm{~kg}$ and a mean weight of $6.00 \pm 2.55 \mathrm{~kg}$ (Figure 7). For females, weight ranged from $0.5 \mathrm{~kg}$ to $6.60 \mathrm{~kg}$, with a dominant weight class of $2.5-4.5 \mathrm{~kg}$ and mean weight of $2.23 \pm 0.77 \mathrm{~kg}$ (Figure 8).

\section{Age-based cohorts of brown-marbled grouper}

The five age-based cohorts calculated from the lengthfrequency data for both sexes combined, assuming a normal distribution of size within each cohort, are shown in Figure 9. Sex disaggregated cohorts are shown for male (Figure 10) and female (Figure 11) brown marbled groupers. The male groupers comprised 4 cohorts, while female groupers resolved into two main cohorts, with a few larger individuals forming a larger (older) cohort.

The five combined sex age-class cohorts of the brownmarbled grouper species captured in the waters of Takabonerate National Park had mean total length values of $42.08 \mathrm{~cm}, 53.83 \mathrm{~cm}, 65.74 \mathrm{~cm}, 77.6 \mathrm{~cm}$, and $90.48 \mathrm{~cm}$. The male cohort means length was $57.79 \mathrm{~cm}, 66.84 \mathrm{~cm}$, $77.56 \mathrm{~cm}$, and $89.5 \mathrm{~cm}$. Females cohorts had mean lengths of $39.3 \mathrm{~cm}, 50.07 \mathrm{~cm}$, and $63 \mathrm{~cm}$. Given the reported maximum length of $120 \mathrm{~cm}$ and maximum reported longevity of 40 years (Froese and Pauly 2021), these data indicate brown-marbled grouper population dynamics in the waters of Takabonerate National Park, which can be considered typical of excessive rates of fishing pressure over an extended period of time.

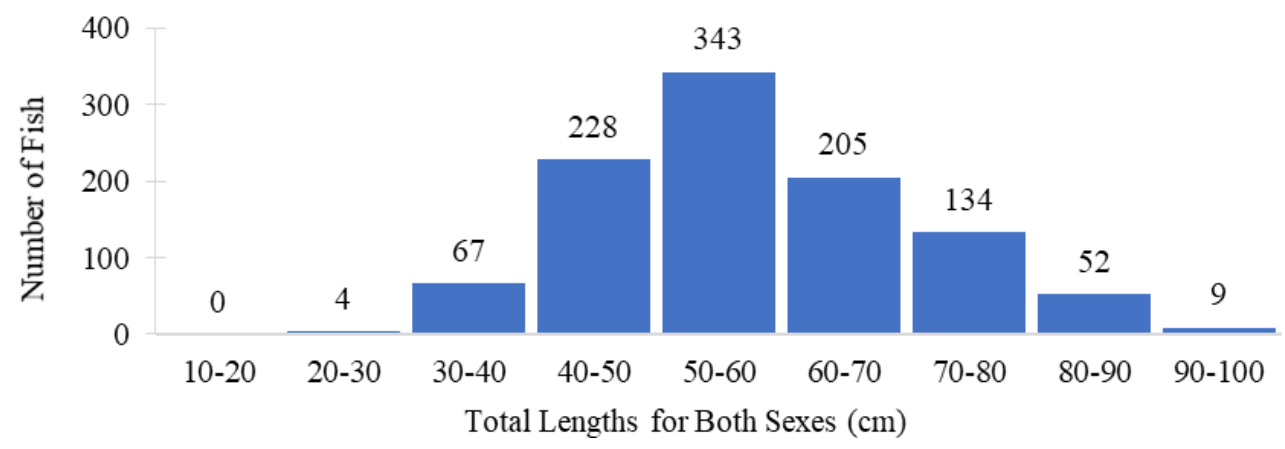

Figure 3. Length-frequency histogram of brown-marbled grouper (both sexes combined) 


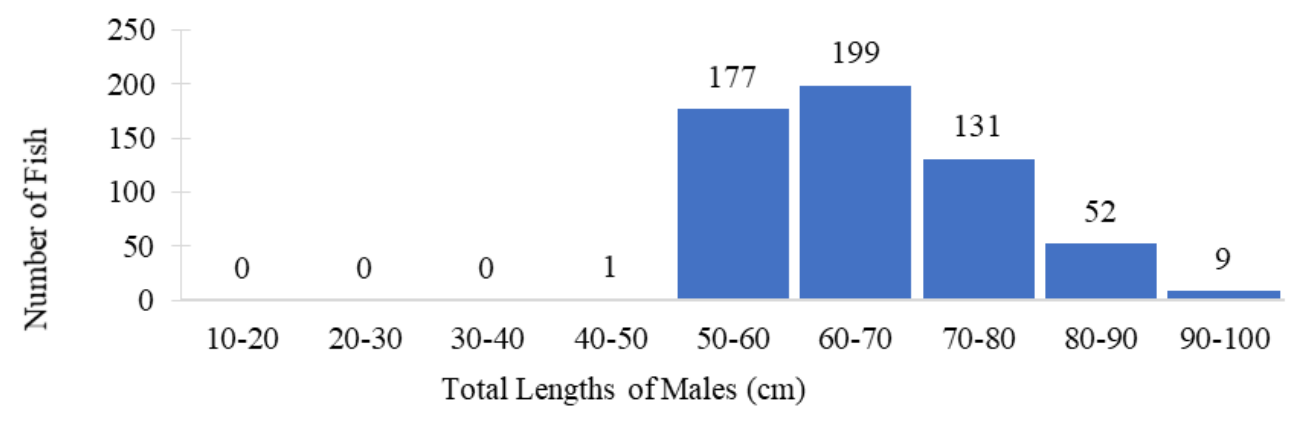

Figure 4. Length-frequency histogram of male brown-marbled grouper

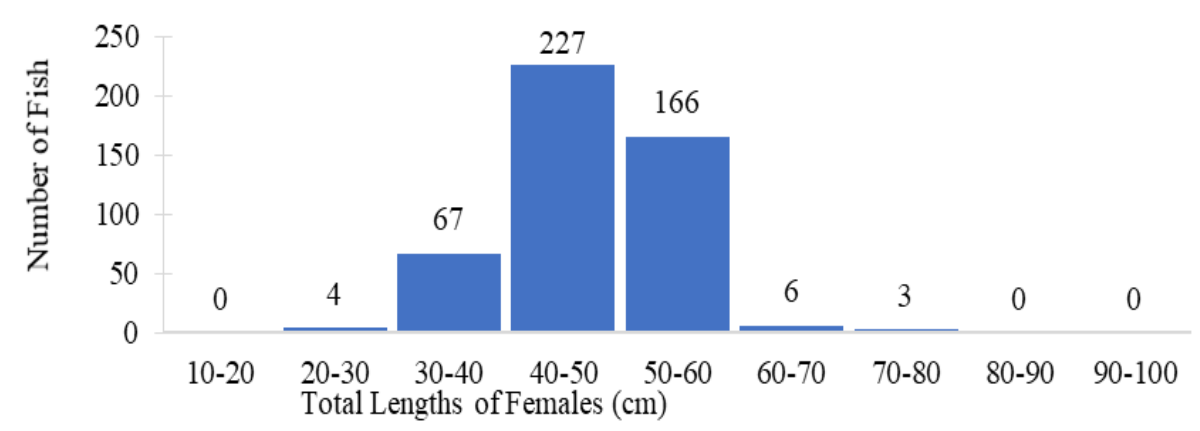

Figure 5. Length-frequency histogram of female brown-marbled grouper

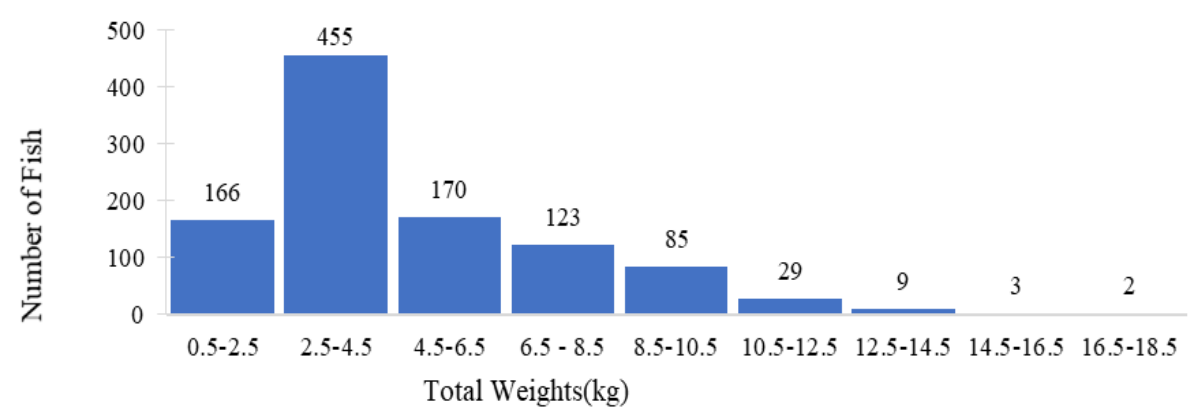

Figure 6. Weight distribution of brown-marbled grouper (both sexes combined)

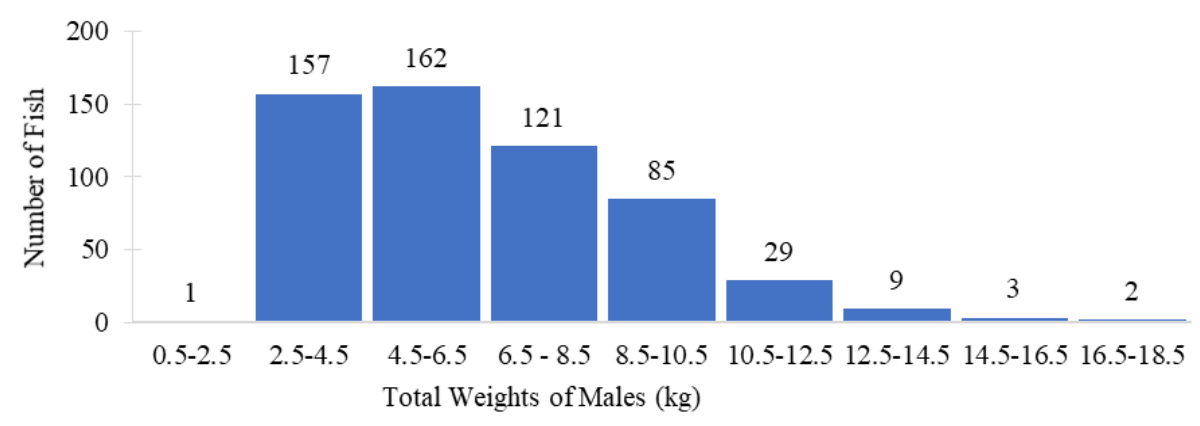

Figure 7. Weight distribution of male brown-marbled grouper 


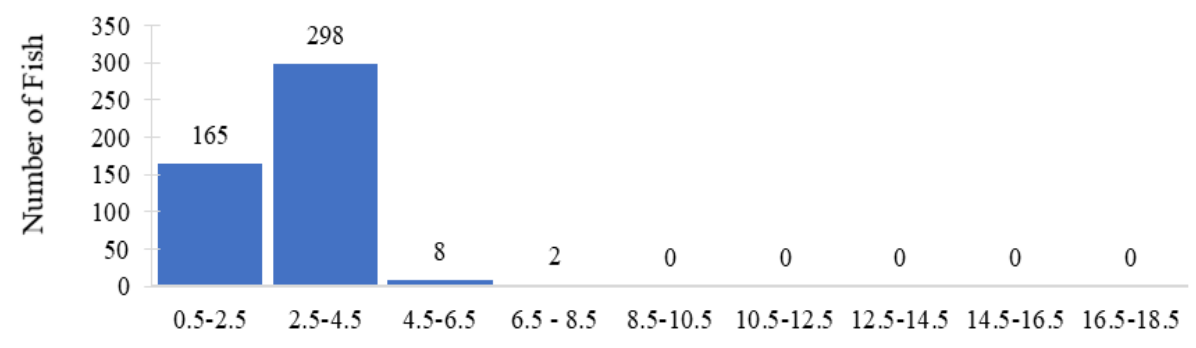

Total Weights of Females (kg)

Figure 8. Weight distribution of female brown-marbled grouper

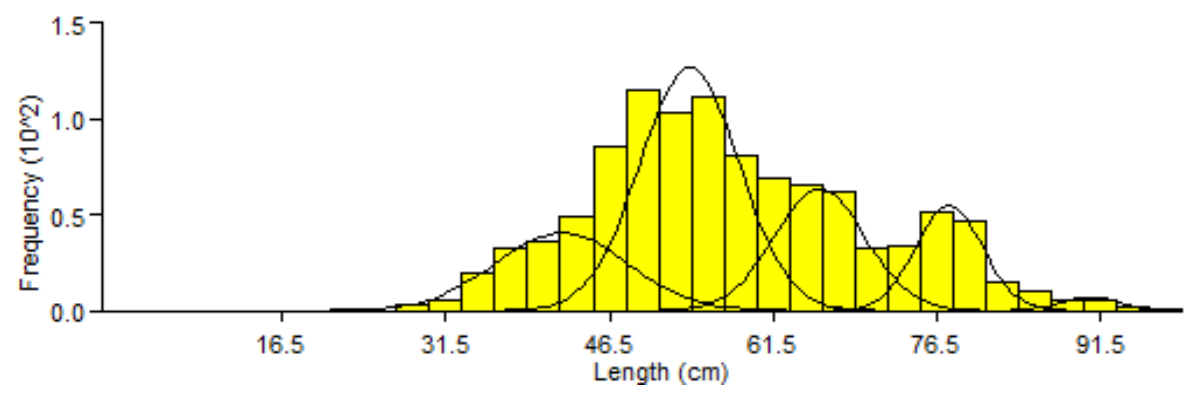

Figure 9. Length-frequency-based cohorts of brown-marbled grouper in the Takabonerate National Park, South Sulawesi, Indonesia

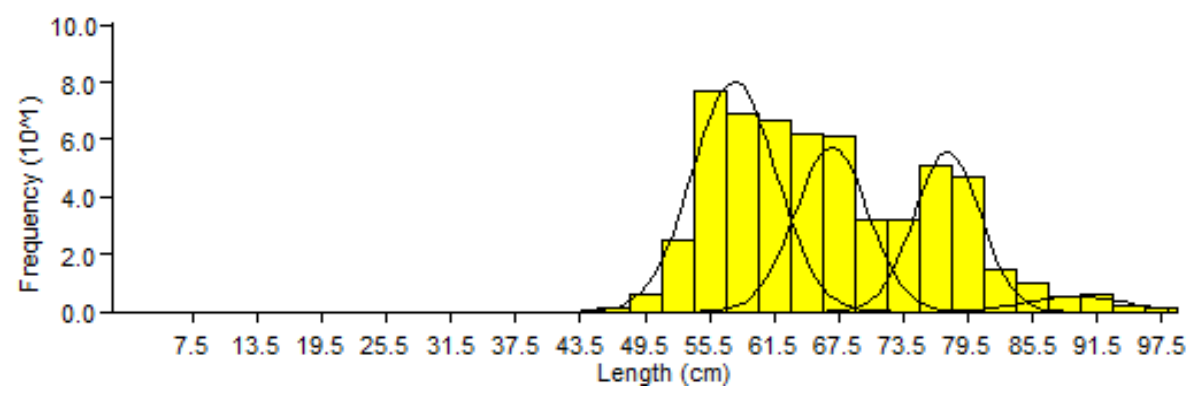

Figure 10. Length-frequency-based cohorts of male brown-marbled grouper in the Takabonerate National Park, South Sulawesi, Indonesia

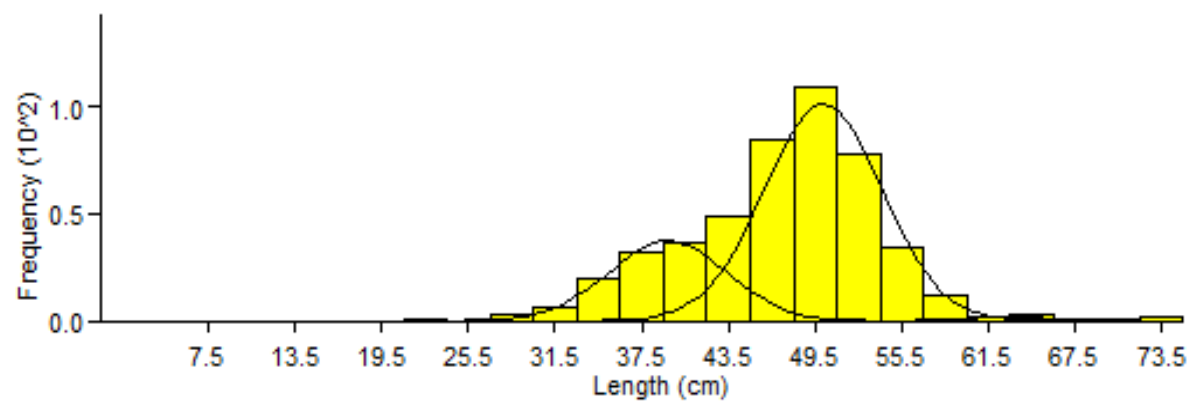

Figure 11. Length-frequency-based cohorts of female brown-marbled grouper in the Takabonerate National Park, South Sulawesi, Indonesia

\section{Growth of the brown-marbled grouper}

The von Bertalanffy curve used to model the growth of the brown-marbled grouper in the waters of Takabonerate National Park show the exponential growth equations obtained from the length-frequency data for the total sample (both sexes combined) is shown in Figure 12. Similar curves for male and female groupers are shown in Figure 13 and Figure 14, respectively.
Growth parameters varied considerably between male and female brown marbled groupers (Table 1). The growth coefficients obtained for brown-marbled groupers were 0.46 year $^{-1}$ for both sexes combined, 0.42 year $^{-1}$ for males and 0.62 year $^{-1}$ for females.

Mallawa and Amir (2019) contend that a higher K value for a given population reflects a shorter period of time required for fishes in the population to reach the asymptotic 
length $\left(\mathrm{L}_{\infty}\right)$. The growth parameters for males can be considered typical of slow growth rates, with $\mathrm{K}<0.5$ year${ }^{1}$, suggestive of a long time required to allow an individual to reach its asymptotic length $\left(\mathrm{L}_{\infty}\right)$. Conversely, for females the parameters indicate a higher growth rate with $\mathrm{K}>0.5$ year $^{-1}$; such a relatively rapid growth rate should enable individuals to attain the lower asymptotic length $\left(\mathrm{L}_{\infty}\right)$ for females.

The growth parameters of brown-marbled grouper obtained from this study were compared with values obtained for conspecific and congeneric grouper populations in other studies (Table 2). These data show wide variations between and within species and indicate that the Takabonerate National Park population has a relatively high asymptotic length and fast growth compared to conspecific populations in Australia and Papua New Guinea.

Table 1. Growth parameters by sex for brown-marbled grouper in the waters of Takabonerate National Park, South Sulawesi, Indonesia based on the von Bertalanffy model (ELEFAN I in FISAT II.)

\begin{tabular}{lccc}
\hline \multicolumn{1}{c}{ Parameter } & $\begin{array}{c}\text { Both } \\
\text { sexes }\end{array}$ & Males & Females \\
\hline Growth coefficient $(\mathrm{K})$ & $0.46 /$ year & $0.42 /$ year & $0.62 /$ year \\
Asymptotic length $\mathrm{L}_{\infty}$ & $109.0 \mathrm{~cm}$ & $121.3 \mathrm{~cm}$ & $79.0 \mathrm{~cm}$ \\
Log $\left(-\mathrm{t}_{\mathrm{o}}\right)$ & -0.6028 & -0.5746 & -0.7132 \\
$\mathrm{t}_{\mathrm{o}}$ & $-0.2496 /$ & $-0.2663 /$ & $-0.1935 /$ \\
& year & year & year \\
Growth Performance & 3.73761 & 3.79061 & 3.60143 \\
Index $(\varphi)$ & & & \\
\hline
\end{tabular}

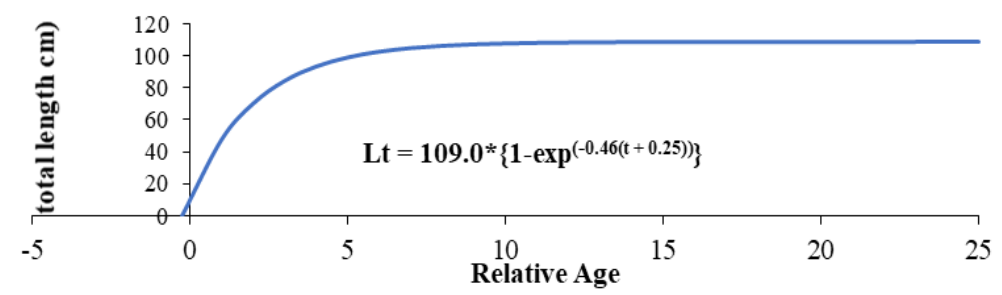

Figure 12. Growth curve of brown-marbled grouper based on the von Bertalanffy model

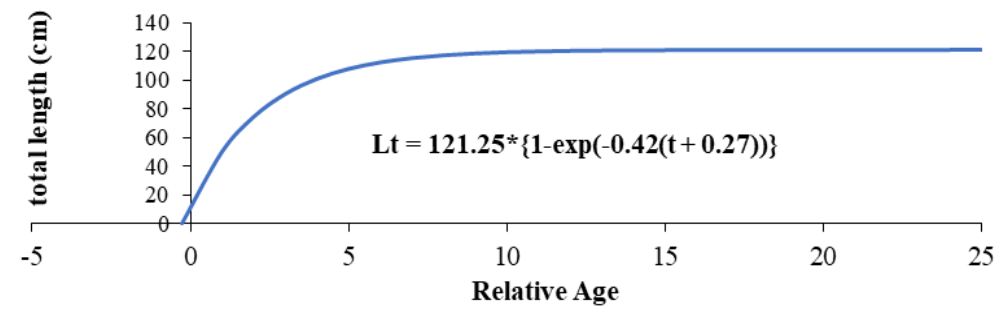

Figure 13. Growth curve of male brown-marbled grouper based on the von Bertalanffy model

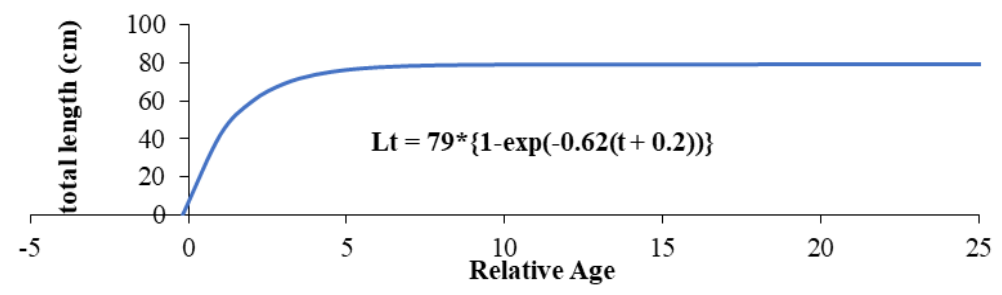

Figure 14. Growth curve of female brown-marbled grouper based on the von Bertalanffy model

Table 2. $\mathrm{L}_{\infty}$ and $\mathrm{K}$ values from several studies on brown-marbled grouper and other types of grouper across different areas

\begin{tabular}{llcll}
\hline \multicolumn{1}{c}{ Locations } & \multicolumn{2}{c}{ Species } & \multicolumn{2}{c}{ Parameter of Growth } \\
\cline { 2 - 5 } & & L $_{\infty}$ & \multicolumn{1}{c}{ K } & \multicolumn{2}{c}{ Reference } \\
\hline Arabian Gulf, Saudi Arabia & Epinephelus coioides & 102.7 & 0.15 & Tharwat 2005 \\
Andaman Island & Epinephelus malabaricus & 124.60 & 0.80 & Kirubasankar et al. 2013 \\
Shallow Waters of Semak Daun, Seribu Islands & Epinephelus fuscoguttatus & 97.48 & 0.27 & Kurnia 2012 \\
Great Barrier Reef & Epinephelus fuscoguttatus & 80.7 & 0.16 & Froese and Pauly 2021 \\
Kavieng, Papua New Guinea & Epinephelus fuscoguttatus & 99.1 & 0.16 & Froese and Pauly 2021 \\
Takabonerate National Park Waters & Epinephelus fuscoguttatus & 109.0 & 0.46 & This study \\
& E. fuscoguttatus (males) & 121.3 & 0.42 & \\
& E. fuscoguttatus (females) & 79.0 & 0.62 & \\
\hline
\end{tabular}




\section{Mortality and exploitation rate of brown-marbled grouper}

The exploitation rate (E) is generally estimated by dividing the fishing mortality rate $(F)$ by the total mortality rate $(\mathrm{Z})$. The catch curves of brown-marbled grouper in the waters of Takabonerate National Park based on the lengthfrequency data (Figure 15) illustrated the mortality rates for the combined population (A) and disaggregated by sex (B and C). A summary of the results is given in Table 3.

The natural mortality (M) of brown-marbled grouper was quite high (Tables 3 and 4); however, the fishing mortality rates $(\mathrm{F})$ of brown-marbled grouper in the waters of Takabonerate National Park were higher than natural mortality (M). This high proportion of fishing mortality strongly indicates that fishing practices were the primary cause of mortality in the brown-marbled grouper population in the waters of Takabonerate National Park. The exploitation rate $(\mathrm{E})$ was high for both sexes combined and for each sex, being highest for females (Table 3). According to Gulland (1971), rates of $\mathrm{E}>0.05$ are indicative of a pattern of overexploitation.

A comparison of the mortality and exploitation rates between the mortality and exploitation rates of brownmarbled grouper in Takabonerate National Park with other grouper fisheries (Table 4) shows exploitation rates typically above 0.5 and indicates that overexploitation of grouper stocks is common across regions and species. The data show that mortality rates $(\mathrm{M}, \mathrm{F}$, and $\mathrm{Z}$ ) for the Takabonerate National Park brown marbled grouper population lie within previously reported ranges. However, total mortality for females and fishing mortality (overall and by sex) was the second-highest, only exceeded for the Leopard coral grouper (Plectropomus leopardus) population in Rumberpon Waters, Cendrawasih Gulf National Park (Bawole et al. 2018).

Table 3. Mortality and exploitation rates (Z, M, F and E) of brown-marbled grouper in Takabonerate National Park, South Sulawesi, Indonesia by sex

\begin{tabular}{lccc}
\hline \multicolumn{1}{c}{ Mortality rate } & \multicolumn{3}{c}{ Estimated value (per year) } \\
\cline { 2 - 4 } & Both sexes & Males & Females \\
\hline Total mortality (Z) & 2.19 & 2.67 & 3.13 \\
Confidence interval of Z & $1.79-2.60$ & $1.90-3.44$ & $1.80-4.46$ \\
Natural mortality (M) & 0.77 & 0.71 & 1.05 \\
Fishing mortality (F) & 1.42 & 1.96 & 2.08 \\
Exploitation rate (E) & 0.65 & 0.73 & 0.66 \\
\hline
\end{tabular}

Table 4. Mortality and exploitation rates (Z, M, F and E) for brown-marbled grouper in Takabonerate National Park, South Sulawesi, Indonesia and other Indo-Pacific grouper populations

\begin{tabular}{|c|c|c|c|c|c|c|}
\hline \multirow{2}{*}{ Location } & \multirow{2}{*}{ Type of grouper } & \multicolumn{4}{|c|}{ Mortality } & \multirow{2}{*}{ Reference } \\
\hline & & $\mathbf{M}$ & $\mathbf{F}$ & $\mathbf{Z}$ & $\mathbf{E}$ & \\
\hline \multirow[t]{3}{*}{ Lasongko Gulf, Buton District } & E. fuscoguttatus & 0.49 & 0.54 & 1.03 & 0.53 & \multirow[t]{3}{*}{ Prasetya $(2010)$} \\
\hline & E. coioides & 0.59 & 0.65 & 1.24 & 0.52 & \\
\hline & P. leopardus & 0.49 & 0.52 & 1.01 & 0.51 & \\
\hline Semak Daun Waters, Seribu Islands & E. fuscoguttatus & \multicolumn{5}{|c|}{$0.56-0.580 .4-0.50 .910 .44-0.55$ Kurnia (2012) } \\
\hline Wakatobi National Park & Groupers & 0.9 & 0.66 & 1.56 & 0.58 & Tadjuddah et al. (2012) \\
\hline Andaman Island & E. malabaricus & 1.05 & 1.48 & 2.53 & 0.58 & Kirubasankar et al. (2013) \\
\hline \multirow[t]{2}{*}{ Peukan Bada Waters, Aceh Besar } & E. fasciatus & 0.49 & 0.79 & 1.28 & 0.62 & \multirow[t]{2}{*}{ Astuti (2016) } \\
\hline & Cephalopholis sonnerati & 0.33 & 0.4 & 0.73 & 0.55 & \\
\hline Cendrawasih Gulf National Park & Plectropomus leopardus & 0.75 & 0.86 & 1.61 & 0.53 & Bawole et al. (2017) \\
\hline $\begin{array}{l}\text { Rumberpon Waters, Cendrawasih } \\
\text { Gulf National Park }\end{array}$ & P. leopardus & 0.99 & 3.86 & 4.85 & 0.79 & Bawole et al. (2018) \\
\hline Sarappo Island, Pangkep District & P. leopardus & 1.28 & 1.75 & 3.03 & 0.58 & Ernaningsih et al. (2019) \\
\hline Southwest Coast of India & E. diacanthus & 0.66 & 0.67 & 1.33 & 0.5 & Ramachandran and Ramalingam (2020) \\
\hline Karimunjawa Waters & C. cyanostigma & 0.78 & 0.99 & 1.77 & 0.56 & Prihatiningsih et al. (2020) \\
\hline \multirow[t]{3}{*}{ Takabonerate National Park } & E. fuscoguttatus & 0.77 & 1.42 & 2.19 & 0.65 & \multirow[t]{3}{*}{ This study } \\
\hline & E. fuscoguttatus (males) & 0.71 & 1.96 & 2.67 & 0.73 & \\
\hline & E. fuscoguttatus (females) & 1.05 & 2.08 & 3.13 & 0.66 & \\
\hline
\end{tabular}

Note: M: Natural mortality, F: Fishing mortality, Z: Total mortality, E: Exploitation rate 


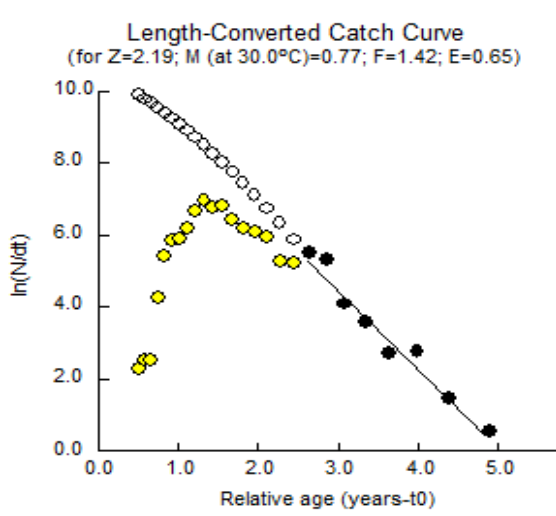

A

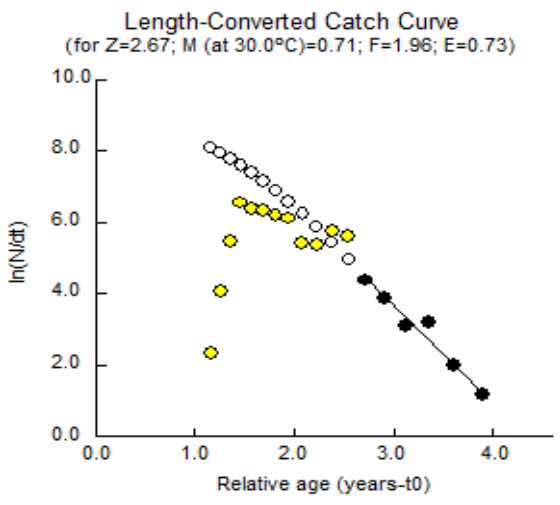

B

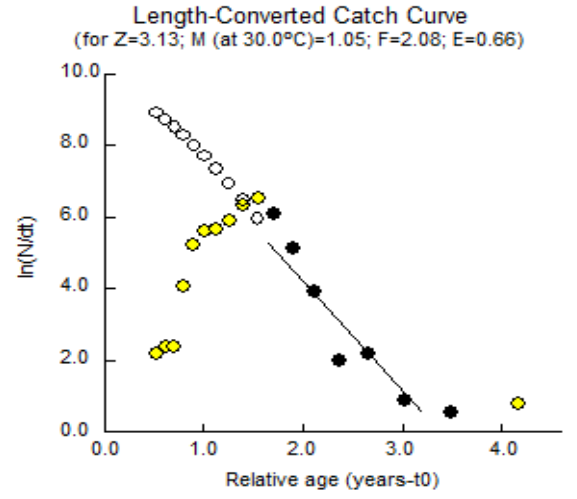

C

Figure 15. Length-converted catch curves for brown-marbled grouper in the waters of Takabonerate National Park, South Sulawesi, Indonesia by sex. A. Brown-Marbled Grouper (Both Sexes Combined); B. Male Brown-Marbled Grouper; C. Female Brown-Marbled Grouper

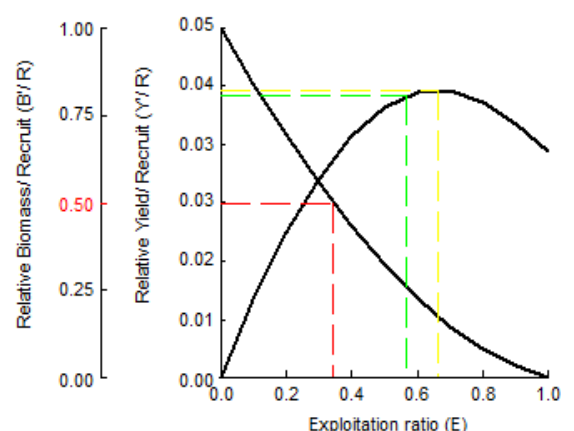

$\mathbf{A}$

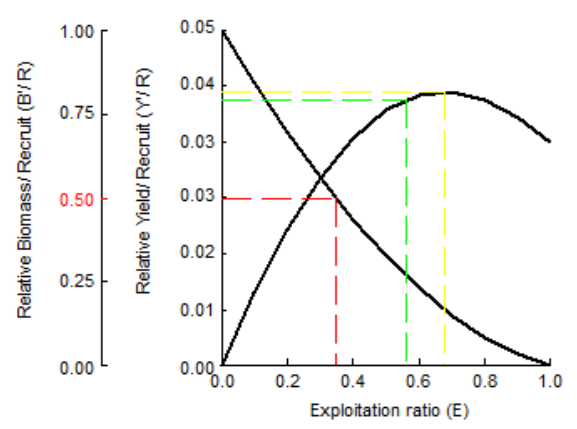

B
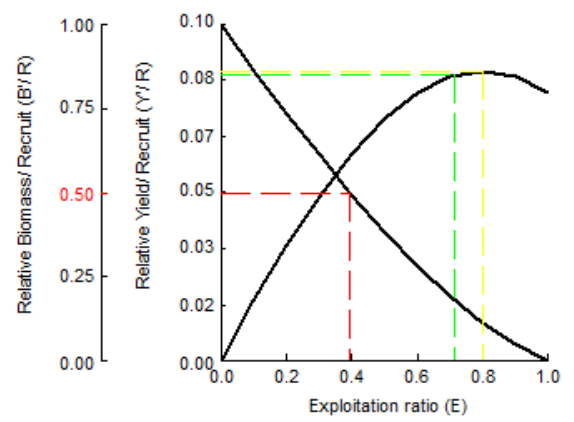

C

Figure 16. Relationship between Yield per Recruit (Y/R) and Exploitation Rate (E) by Sex for Brown-Marbled Grouper in the Waters of Takabonerate National Park, Selayar Islands District, Indonesia (legend: red: Current Rate of Exploitation Rate (E); green: Yield per Recruit (Y/R); yellow: Exploitation Rate Maximal/E Optimal). A. Brown-Marbled Grouper (Both Sexes Combined); B. Male BrownMarbled Grouper; C. Female Brown-Marbled Grouper

\section{Yield per Recruit (Y/R)}

The relationship between exploitation rate (E) and yield per recruit $(\mathrm{Y} / \mathrm{R})$ can be used as a reference variable or indicator for assessing whether the current exploitation rate is optimal, sub-optimal, or excessive (overexploitation) in comparison to the capacity of the stock to regenerate through recruitment. The relationship between (E) and $(\mathrm{Y} / \mathrm{R})$ based on the length-frequency data from brown marbled grouper samples captured in the waters of Takabonerate National Park is shown in Figure 16 for both sexes combined (A) and by disaggregated by sex (B and C).

The $\mathrm{Y} / \mathrm{R}$ was estimated from the values of $\mathrm{L}^{\infty}, \mathrm{K}, \mathrm{Lc}$, $\mathrm{M}$, and $\mathrm{E}$ obtained previously using the basic assumptions of the Beverton and Holt method (Sparre and Venema 1999). Based on the yield per recruit data analysis and processing, the current exploitation rate (E) was recorded as 0.345 and the actual $\mathrm{Y} / \mathrm{R}$ at $0.03 \mathrm{~g} /$ recruit. The maximum exploitation rate (E Opt.) was 0.661, and the optimum Y/R was $0.040 \mathrm{~g} /$ recruit. The actual $\mathrm{Y} / \mathrm{R}$ was lower than the optimum $\mathrm{Y} / \mathrm{R}$, which indicates poor recruitment success. A situation in which the actual $Y / R$ is less than the optimum $\mathrm{Y} / \mathrm{R}$ is generally attributable to a population or stock experiencing a high exploitation rate $(\mathrm{E}$ $>0.5$ per year). As stated by Mallawa et al. (2007), a state of high exploitation in a given population or stock leads to a condition in which peak recruitment phases fail. The sexdisaggregated yield per recruit analysis for male brownmarbled groupers gave a current exploitation rate (current E) of 0.348 and an actual $\mathrm{Y} / \mathrm{R}$ of $0.03 \mathrm{~g} /$ recruit. The maximum exploitation rate (E Opt.) and the optimum Y/R were calculated as 0.676 and $0.042 \mathrm{~g} /$ recruit, respectively. The statistics for the females did not differ significantly from the males with a current $E$ of 0.395 and an actual Y/R of $0.05 \mathrm{~g} /$ recruit; however, E Opt. was 0.802 , and the optimum Y/R was $0.1196 \mathrm{~g} /$ recruit. These results provide evidence of poor recruitment success, as indicated by actual $Y / R$ values less than the optimum $Y / R$ values. Low levels of actual $\mathrm{Y} / \mathrm{R}$ will hinder the potential of spawning closures to contribute towards sustaining the brownmarbled grouper stocks and enabling long-term exploitation. It is, therefore, crucial to take action and improve measures regulating fishing activities to ensure 
fishing effort is commensurate with the reproductive capacity of the brown-marbled grouper stocks.

In conclusion, the size structure of the brown-marbled grouper captured in the waters of Takabonerate National Park varied considerably between males and females. Five age-specific cohorts were identified. Based on the growth coefficient ( 0.46 year-1), brown-marbled groupers in these waters have a relatively slow growth rate $(\mathrm{K}<0.5$ year-1) with an asymptotic length $(\mathrm{L} \infty)$ of $109 \mathrm{~cm}$ and a low probability that individuals within the population would approach the asymptotic length. The mortality and exploitation analysis revealed a rate of fishing mortality higher than natural mortality while actual yield per recruit (Y/R) was below the optimum Y/R. Overall, the assessment indicates that the brown-marbled grouper population in the waters of Takabonerate National Park is overexploited, experiencing high mortality due to poorly regulated fishing practices, and furthermore, the population has poor recruitment success.

\section{ACKNOWLEDGEMENTS}

We wish to extend our sincere gratitude and appreciation to all who contributed to this study in any way. In particular, we thank the Takabonerate National Park Service, South Sulawesi, Indonesia and all who provided assistance and support in the field and during the analysis stages of the study.

\section{REFERENCES}

Astuti R. 2016. Analisis Populasi Ikan Kerapu (Serranidae) yang Tertangkap di Perairan Peukan Bada, Aceh Besar, Provinsi Aceh. [Thesis]. Sekolah Pascasarjana, IPB University, Bogor. [Indonesian]

Bhattacharya. C. G. 1974. A Simple Method of resolution, A. Distribution intoCoasien Component Biometrics. Biometric 23: 115-135.

Bawole R, Mudjirahayu, Unstain NWJ, Amir A, Runtuboi F, Sala. 2017. Growth and mortality rate of the Napan-Yaur Coral Trout, Plectropomus leopardus (Pisces: Serranidae), Cenderawasih Bay National Park, Indonesia. Biodiversitas 18 (2): 758-764. DOI: 10.13057/biodiv/d180245

Bawole R, Mudjirahayu, Unstain NWJ, Amir A, Runtuboi F, Sala. 2018. Exploitation rate of Plectropomus leopardus (Pisces: Serranidae) taken from Rumberpon Island water, Cenderawasih Bay National Park, Indonesia. AACL Bioflux 11 (1): 19-28.

Balai Taman Nasional Taka Bonerate. 2019. Taman Nasional Taka Bonerate. Direktorat Jenderal Konservasi Sumberdaya Alam dan Ekosistem, Kementerian Lingkungan Hidup dan Kehutanan, Jakarta. [Indonesian]

Ernaningsih, Asbar, Danial, Hasrun A, Jamal M. 2019. Population dynamics and exploitation ate of coral grouper Plectropomus leopardus in the Sarappo Islands, Pangkep District, South Sulawesi. IOP Conf Ser Earth Environ Sci 253: 012028. DOI: 10.1088/1755$1315 / 253 / 1 / 012028$

Froese R, Pauly D. 2021. Epinephelus fuscoguttatus (Forsskål, 1775) Brown-marbled Grouper. FishBase, the Global Database of Fishes. https://www.fishbase.se/summary/4460

Gayanilo FC, Sparre P, Pauly D. 2005. FAO-ICLARM Stock Assessment Tools II: FiSAT II: User's Guide. World Fish Center and Food and Agriculture Organization of the United Nations, Rome.

Gulland JA. 1971. The Fish Resources of the Ocean. Fishing News (Books) Ltd West Byfleet, Surrey.
Hixon MA, Johnson DW, Sogard SM. 2014. BOFFFFs: On the importance of conserving old-growth age structure in fishery populations. ICES J Mar Sci 71: 2171-2185. DOI: 10.1093/icesjms/fst200

Khasanah M, Kadir NN, Jompa J. 2019. Reproductive biology of three important threatened/near-threatened groupers (Plectropomus leopardus, Epinephelus polyphekadion and Plectropomus areolatus) in Eastern Indonesia and implications for management. Animals 9: 118. DOI: $10.3390 /$ ani9090643

Kurnia R. 2012. Model Restocking Kerapu Macan (Epinephelus fuscoguttatus) dalam Sistem Sea Ranching di Perairan Dangkal Semak Daun, Kepulauan Seribu. [Dissertation]. IPB University, Bogor. [Indonesian]

Kirubasankar R, Dam RS, Grinson G, Sarma K, Krishnan P, Kaliyamoorthy M, Gouthambharathi MP. 2013. Fishery and exploitation of Malabar, Epinephelus malabaricus (Bloch and Schneider 1801) from Andaman Island. Asian Fish Sci 26: 167-175. DOI: $10.33997 /$ j.afs.2013.26.3.004

Mallawa A. 2007. Pengelolaan Sumberdaya Perikanan Berbasis Masyarakat. Coremap II, Selayar. [Indonesian]

Mallawa A. 2011. Model Dinamika Populasi dan Evaluasi Stok. Bagian I: Model Dinamika dan Evaluasi Populasi. Lembaga Pengkajian dan Pengembangan Pendidikan, Universitas Hasanuddin, Makassar. [Indonesian]

Mallawa A, Amir F, Sitepu F. 2014. Biologi Populasi dan Aspek Perikanan Ikan Cakalang (Katsuwonus pelamis) Perairan Selat Makassar. LP2M. Universitas Hasanuddin, Makassar. [Indonesian]

Mallawa A, Amir F, Susanti W. 2015. Kondisi stok ikan cakalang (Katsuwonus pelamis) di Perairan Laut Flores, Sulawesi Selatan. Prosiding Seminar Nasional Kelautan Perikanan II. Hasanuddin University, Makassar, 5 Oktober2015. [Indonesian]

Mallawa A, Amir F. 2019. Population dynamic of narrow-barred spanish mackerel (Scomberomorus commerson) in Bone Bay Waters, South Sulawesi, Indonesia. AACL Bioflux 12 (3): 908-917.

MMAF. 2016. Potensi dan Tingkat Pemanfaatan Sumberdaya Ikan di Wilayah Pengelolaan Perikanan Republik Indonesia (WPP RI). Balai Penelitian Perikanan Laut. Pusat Penelitian Pengelolaan Perikanan dan Konservasi Sumberdaya Ikan. Badan Penelitian dan Pengembangan Kelautan dan Perikanan, Indonesia. [Indonesian]

Pauly, D. 1984. Fish Population Dynamics in Tropical Waters: A Manual for Use with Programmable Calculators. ICLARM Studies and Reviews 8, Manila.

Pears R, Choat J, Mapstone B, Begg G. 2006. Demography of a large grouper, Epinephelus fuscoguttatus, from Australia's Great Barrier Reef: implications for fishery management. Mar Ecol Prog Ser 307: 259-272. DOI: $10.3354 /$ meps 307259

Prasetya R. 2010. Potensi dan Laju Eksploitasi Sumberdaya Ikan Kerapu di Perairan Teluk Lasongko Kabupaten Buton Sulawesi Tenggara. [Thesis]. IPB University, Bogor. [Indonesian]

Prihatiningsih, Edrus IN, Hartati ST. 2019. Parameter populasi ikan kerapu karang bintik biru (Cephalopholis cyanostigma, Valenciennes, 1828) di perairan Karimunjawa, Jawa Tengah. Bawal 11 (1): 59-68. DOI: 10.15578/bawal.11.1.2019.59-68. [Indonesian]

Ramachandran, Ramalingam. 2020. Population dynamics of spinycheek grouper Epinephelus diacanthus (Valenciennes, 1828) from the southwest coast of India. Intl J Fish Aquat Stud 8 (5): 299-307. DOI: 10.22271/fish.2020.v8.i5d.2337

Sparre P, Ursin E, Venema SC. 1999. Introduction to Tropical Fish Stock Assessment. Part I. Food and Agriculture Organisation of the United Nations (FAO), Rome.

Sparre P, Venema SC. 1999. Introduction to Tropical Fish Assessment. Manual Book 1. Food and Agriculture Organisation of the United Nations (FAO), Rome.

Tharwat AA. 2005. Stock assessment of orange-spotted grouper Epinephelus coioides inhabiting the Arabian Gulf at Saudi Arabia. Saudi J Biol Sci 12 (2): 81-89.

Tadjuddah M, Wiryawan B, Purbayanto A, Wiyono ES. 2013. Analisis parameter biologi ikan kerapu (Epinephelus sp.) di Perairan Taman Nasional Wakatobi, Sulawesi Tenggara Indonesia. Jurnal Teknologi dan Manajemen Perikanan Laut 4 (1): 11-21. DOI: 10.29244/jmf.4.1.11-21. [Indonesian] 